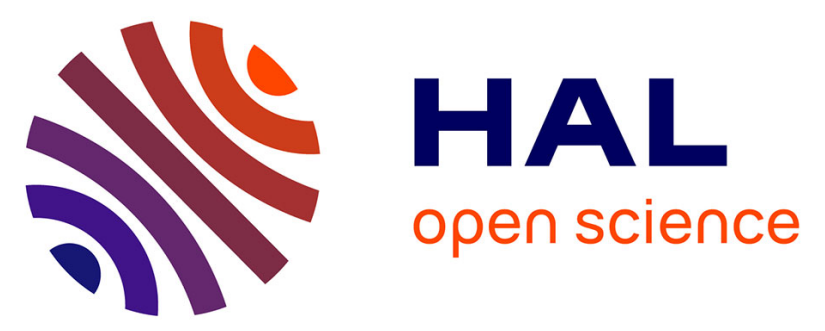

\title{
Toxicity removal assessments related to degradation pathways of azo dyes: Toward an optimization of Electro-Fenton treatment
}

Thi Xuan Huong Le, Thi Van Nguyen, Zoulkifli Amadou Yacouba, Laetitia Zoungrana, Florent Avril, Eddy Petit, Julie Mendret, Valerie Bonniol, Mikhael Bechelany, Stella Lacour, et al.

\section{To cite this version:}

Thi Xuan Huong Le, Thi Van Nguyen, Zoulkifli Amadou Yacouba, Laetitia Zoungrana, Florent Avril, et al.. Toxicity removal assessments related to degradation pathways of azo dyes: Toward an optimization of Electro-Fenton treatment. Chemosphere, 2016, 161, pp.308 - 318. 10.1016/j.chemosphere.2016.06.108 . hal-01687166

\section{HAL Id: hal-01687166 \\ https://hal.umontpellier.fr/hal-01687166}

Submitted on 7 Jul 2021

HAL is a multi-disciplinary open access archive for the deposit and dissemination of scientific research documents, whether they are published or not. The documents may come from teaching and research institutions in France or abroad, or from public or private research centers.
L'archive ouverte pluridisciplinaire HAL, est destinée au dépôt et à la diffusion de documents scientifiques de niveau recherche, publiés ou non, émanant des établissements d'enseignement et de recherche français ou étrangers, des laboratoires publics ou privés. 


\title{
Toxicity removal assessments related to degradation pathways of azo dyes: toward an optimization of electro-Fenton treatment
}

Thi Xuan Huong Le, Thi Van Nguyen, Zoulkifli Amadou Yacouba, Laetitia Zoungrana, Florent Avril, Eddy Petit, Julie Mendret, Valerie Bonniol, Mikhael Bechelany, Stella Lacour, Geoffroy Lesage*, Marc Cretin* $^{*}$

IEM (Institut Européen des Membranes), UMR 5635 (CNRS-ENSCM-UM), Université de Montpellier, Place E. Bataillon, F- 34095, Montpellier, France.

Corresponding authors Email: Geoffroy.Lesage@umontpellier.fr, Marc.Cretin@umontpellier.fr

\begin{abstract}
The degradation pathway of Acid Orange 7 (AO7) by Electro-Fenton process using carbon felt cathode was investigated via HPLC-UV and LC-MS, IC, TOC analysis and bioassays (Vibrio Fischeri $81.9 \%$ Microtox ${ }^{\circledR}$ screening tests). The TOC removal of AO7 reached $96.2 \%$ after $8 \mathrm{~h}$ treatment with the optimal applied current density at $-8.3 \mathrm{~mA} . \mathrm{cm}^{-2}$ and $0.2 \mathrm{mM}$ catalyst concentration. The toxicity of treated solution increased rapidly to its highest value at the early stage of electrolysis (several minutes), corresponding to the formation of intermediate poisonous aromatic compounds such as 1,2-naphthaquinone (NAPQ) and 1,4-benzoquinone (BZQ). Then, the subsequent formation of aliphatic short-chain carboxylic acids like acetic acid, formic acid, before the complete mineralization, leaded to a non-toxic solution after $270 \mathrm{~min}$ for $500 \mathrm{~mL}$ of AO7 (1 mM). Moreover, a quantitative analysis of inorganic ions (i.e. ammonium, nitrate, sulfate) produced during the course of degradation could help to verify molar balance with regard to original nitrogen and sulfur elements. To conclude, a clear degradation pathway of AO7 was proposed, and could further be applied to other persistent pharmaceuticals in aquatic environment.
\end{abstract}

Keywords: Carbon felt, Advanced Oxidation Process, Mineralization, Toxicity, Acid Orange 7.

\section{Introduction}

Textile wastewater is still being of great concern from environmental point of view, in terms of toxicity and persistence. Azo dyes, characterized by the presence of azo group $(-\mathrm{N}=\mathrm{N}-)$, represent approximately $70 \%$ in mass of all dyestuffs used worldwide, making them the largest group of synthetic colorants which are released into the environment. Many of them are known or possible 
toxic, carcinogenic and mutagenic substances that need to be treated before discharge into aqueous medium [1]. Acid Orange 7 (AO7), also called Orange II, is a typical azo dye (Figure 1).

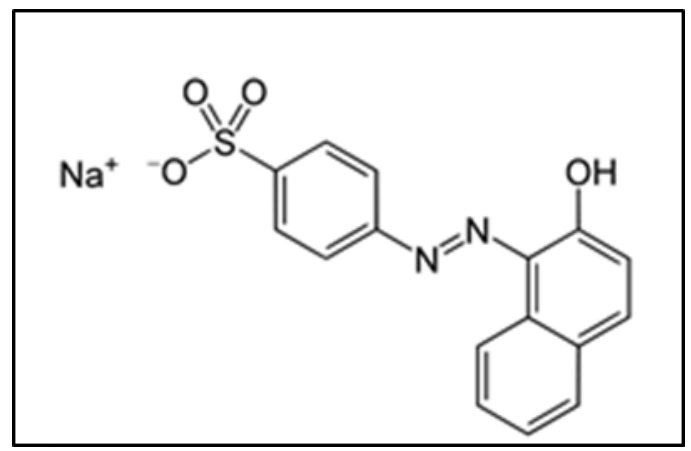

Figure 1. Molecular structure of Acid Orange 7.

Electro-Fenton (EF) process has been known as an environmentally friendly electrochemical technology for the degradation of refractory pollutants in aquatic environment [2]. The principal reaction (equation 1) of the Fenton oxidation process produces hydroxyl radical through the catalyzed reduction of $\mathrm{H}_{2} \mathrm{O}_{2}$ by $\mathrm{Fe}^{2+}$ in an acidic medium.

$$
\mathrm{H}_{2} \mathrm{O}_{2}+\mathrm{Fe}^{2+}+\mathrm{H}^{+} \rightarrow \mathrm{Fe}^{3+}+\cdot \mathrm{OH}+\mathrm{H}_{2} \mathrm{O}
$$

To avoid drawbacks encountered during the Fenton process, mainly $\mathrm{H}_{2} \mathrm{O}_{2}$ transportation potential risk and activity loss, Electro-Fenton (EF) process has been developed. This latter combines the ferrous ion addition with the in-situ electro-generation of $\mathrm{H}_{2} \mathrm{O}_{2}$. The production of $\mathrm{H}_{2} \mathrm{O}_{2}$ in aqueous solution is obtained by electro-reduction of dissolved oxygen (equation 2) under an appropriate applied current (or cathodic potential) [3]. Cathodic electrodes such as vitreous carbon [4], carbon felt [5-8], carbon sponge [9], and gas-diffusion electrode [10] are commonly used for this purpose.

$$
\mathrm{O}_{2}+2 \mathrm{H}^{+}+2 \mathrm{e}^{-} \rightarrow \mathrm{H}_{2} \mathrm{O}_{2}
$$

Thus, hydroxyl radicals can be generated in the solution by addition of a catalytic quantity of $\mathrm{Fe}^{2+}$ ions (equation 1). $\bullet \mathrm{OH}$ can then attack and initiate the oxidation of pollutant $(\mathrm{RH})$ following equation 3.

$$
\bullet \mathrm{OH}+\mathrm{RH} \rightarrow \mathrm{R} \bullet+\mathrm{H}_{2} \mathrm{O}
$$

Commercial carbon felt, used in this study, owns several advantages such as no toxicity, good conductivity, low weight, high chemical resistance, high thermal stability, easy handling and low cost $[11,12]$. This is why it has been applied in various applications relevant to water treatment by electro-Fenton (EF) process [13], vanadium redox flow batteries [14-16], microbial fuel cell [17], and electrochemical technologies $[18,19]$. Used as electrode in EF technology, it exhibits other outstanding properties like: (i) high specific surface area, good mechanical integrity, commercial availability and efficient cathodic regeneration of $\mathrm{Fe}^{2+}\left(\mathrm{Fe}^{3+}+\mathrm{e}^{-} \rightarrow \mathrm{Fe}^{2+}\right)$, which make it an attractive cathode material for EF process [20]; (ii) Adaptable to many various EF systems with 
different shapes as well as areas of electrodes from small $\left(2 \mathrm{~cm}^{2}\right)[7,8]$ to big size $\left(60 \mathrm{~cm}^{2}\right.$ here); and (iii) its physico-chemical stability allows to decline significantly the cost for the EF technology, since it can be continuously used for many cycles (at least 10 cycles) without any decrease of the treatment efficiency.

In the recent studies, AO7 has been chosen as a refractory pollutant which was treated by the advanced oxidation processes (AOPs), such as using electrochemically generated $\bullet \mathrm{OH}$ radicals in acidic aqueous medium by a boron-doped diamond or platinum anode could reach $98 \%$ TOC (Total Organic Carbon) removal after $9 \mathrm{~h}$ of electrolysis [21]. Hydroxyl radicals was also created from Fenton's reagent at the carbon-felt cathode to the removal of nearly 92\% TOC from initial AO7 pollutant after $8 \mathrm{~h}$ treatment [22]. Besides that, AO7 could be decolorized and degraded by an eco-friendly method through the enzymatic mechanisms involved bacteria [1]. The radiolytic degradation of Acid Orange 7 (AO7) in aqueous solutions was investigated to find by-products concerning $\mathrm{N}-\mathrm{N}$ and $\mathrm{C}-\mathrm{N}$ cleavages from mother-molecular [23].

Chemical degradation pathways of dyes by Electrochemical Advanced Oxidation Processes (EAOP) have been extensively studied [8, 9]. However the eco-toxicity study of sub-products generated by the process at different times has not been reported yet. The aim of this work is then to acquire both chemical and eco-toxicological information on the degradation mechanisms of AO7 by Electro-Fenton reaction on carbon felt electrode, while proving that hydroxyl radicals $(\bullet \mathrm{OH})$, a highly powerful oxidizing agent, can mineralize toxic and bio-refractory organic pollutants into non or less toxic compounds. To do this, analytical identification and quantification of targeted molecules and their intermediate sub-products will be carried out by HPLC-UV and LC-MS, IC and TOC analysis, together with toxicity assessments performed during the course of EF process.

The results showed that the decomposition of initial pollutants leaded to the appearance of well identified aromatic compounds at the early stage of the process, followed by the formation of several short-chains carboxylic acids before that complete mineralization into carbon dioxide $\left(\mathrm{CO}_{2}\right)$ and water $\left(\mathrm{H}_{2} \mathrm{O}\right)$ was achieved. Thus, a degradation pathway by the advanced oxidation (electro-Fenton process) at optimal conditions of oxidant dose or oxidation duration reaching to nontoxic products could be constructed thoroughly and systematically for this model pollutant.

The novelty of this work focuses on the evaluation of the toxicity of by-products related to the degradation pathways of azo dye, acid Orange 7. The results were proved tightly via various techniques such as HPLC-UV and LC-MS, IC, TOC analysis and bioassays (Vibrio Fischeri $81.9 \%$ Microtox ${ }^{\circledR}$ screening tests). The work one again points out the high efficiency of EF technology for treatment of bio-refractory pollutants where toxic initial compounds are quickly degraded into non-toxic compounds. 


\section{Materials and methods}

\subsection{Chemicals and bacterial strain}

The carbon felt was purchased from A Johnson Matthey Co., Germany. AO7 (Orange II sodium salt), sodium sulphate (anhydrous, 99.0 - 100.5\%); sodium hydroxide (99\%); sulfuric acid (9597\%); iron (II) sulphate hepta-hydrate (99\%); hydroquinone (HQ); 1,4-benzoquinone (BZQ); 2formyl-benzoic acid (FBA); 1,2-napthoquinone (NAPQ); 2-hydroxyl-1,4-napthalenedione (HNQ); 4-hydroxylbenzenesulphonic acid (HBA); 2-napthol (NOL); oxalic acid (OA); maleic acid (MA); oxamic acid (OMA); fumaric acid (FA) were obtained from Sigma-Aldrich. TOC standard of 1000 mg/L (Sigma-Aldrich Co.) and sodium hydrogen carbonate (99.5\%, ACS, Karlsruhe) were used for total organic and inorganic carbon calibration curves assessments. Bacterial strain of Vibrio fischeri NRRL B-11177 involved in toxicity tests came from Hach Lange GmbH, Germany. Osmotic adjusting solution (MilliQ water with $22 \% \mathrm{NaCl}$ ) and diluent (MilliQ water with 2\% $\mathrm{NaCl}$ ) were used for the preparation of bacterial solutions.

\subsection{Degradation of $\mathrm{AO} 7$ in Electro-Fenton system}

Electro-Fenton experiments were performed at room temperature in a $500 \mathrm{~mL}$ undivided cylindrical glass cell with a two-electrodes system (Figure 2). The applied current was controlled thanks to a power supply (Lambda Electronic, USA) in galvanostatic mode. The carbon felt cathode $\left(60 \mathrm{~cm}^{2}\right)$ was used as working electrode and a platinum cylindrical mesh as counter electrode. The anode was centered in the electrolytic cell, surrounded by the cathode, which covered the inner wall of the cell. The distance between the electrodes was $1.5 \mathrm{~cm}$. The aqueous solution of $\mathrm{AO} 7, \mathrm{Na}_{2} \mathrm{SO}_{4}(50 \mathrm{mM})$ as supporting electrolyte and $\mathrm{FeSO}_{4} .7 \mathrm{H}_{2} \mathrm{O}$ as the catalyst were prepared by adjusting $\mathrm{pH}$ at 3.0 with sulfuric acid $\left(\mathrm{H}_{2} \mathrm{SO}_{4}\right)$. Different conditions of catalyst concentration at $0.05,0.1,0.2,1$ and $2 \mathrm{mM}$ and applied current densities at -1, -1.7, -5, -8.3, and $11.7 \mathrm{~mA} \mathrm{~cm}^{-2}$ were firstly investigated in order to determine the optimal conditions for the mineralization of $200 \mathrm{~mL}$ solutions of $\mathrm{AO} 7$ at $0.1 \mathrm{mM}$.

Then, intermediate compounds monitoring experiment was performed in $500 \mathrm{~mL}$ solution of AO7 $(1 \mathrm{mM}), \mathrm{FeSO}_{4} .7 \mathrm{H}_{2} \mathrm{O}(0.2 \mathrm{mM})$ and applied current density at $-8.3 \mathrm{~mA} \mathrm{~cm}{ }^{-2}$. Prior to the electrolysis, oxygen bubbling was done during 5 minutes in order to saturate the solutions and kept during experiment under continuous magnetic stirring at a rate of $800 \mathrm{rpm}$. Sampling was carried out according to the following time sequence: $0,2,5,6,8,10,12,14,16,18,20,24,28$, $30,35,40,50,60,80,90,100,120,140,160,180,200,220,240,270,300,330,360,390,450$, and $480 \mathrm{~min}$, before their analyses. 


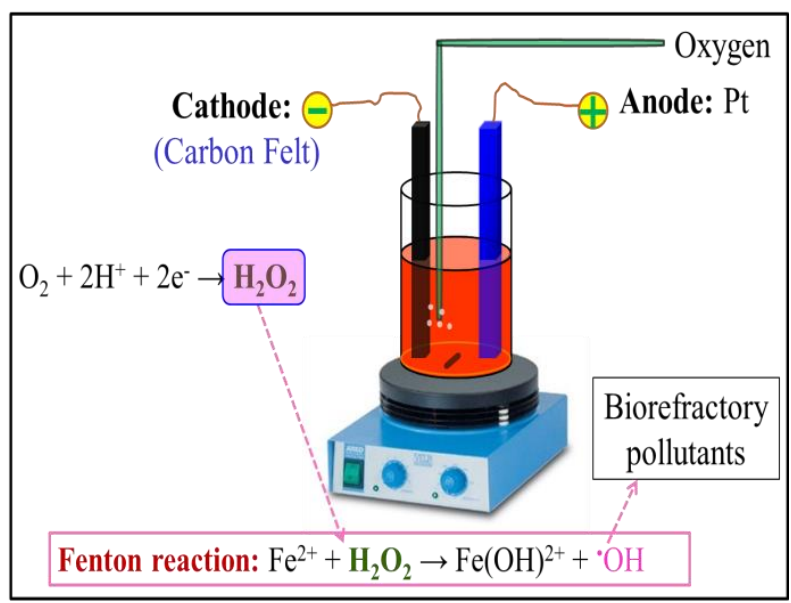

Figure 2. Schematic of the degradation of Acid Orange 7 by EF process.

EF experiments were also performed in a two-separate compartments cell in order to evaluate the influence of anodic oxidation on the degradation of pollutants. Anodic compartment included AO7 (0.1 mM), $\mathrm{Na}_{2} \mathrm{SO}_{4}(50 \mathrm{mM})$ at $\mathrm{pH} 3.0$ and cathodic one comprised $\mathrm{AO} 7(0.1 \mathrm{mM}), \mathrm{Na}_{2} \mathrm{SO}_{4}(50$ $\mathrm{mM}), \mathrm{FeSO}_{4} .7 \mathrm{H}_{2} \mathrm{O}(0.2 \mathrm{mM})$ at $\mathrm{pH}$ 3.0. A proton-exchange membrane (CMX Neosepta from Tokuyama Soda, Japan) was installed as a separator between these two compartments.

\subsection{Analytical methods}

\subsubsection{UV-Vis spectrophotometry analyses}

The absorption spectrum of AO7 consists in four main bands at $\lambda_{\max }$ of 228, 254, 310 and $485 \mathrm{~nm}$. The decomposition of AO7 was monitored by measuring the dye absorbance at the selected single wavelength $\lambda=485 \mathrm{~nm}$ which is characteristic of azo bond. The absorbance of this bond was proportional to the AO7 concentration, according to the Beer-Lambert Law. The apparatus used was a UV-Visible Spectrophotometer Jenway 6300 (Barioworld Scientific Ltd, Dunmow UK).

\subsubsection{High-performance liquid chromatography-UV (HPLC-UV)}

Concentrations of AO7 and their aromatic oxidation by-products were analyzed by a HPLC system (Waters 717 Autosampler and Waters 616 Pump) with a Photodiode Array Detector (Waters 2996 Photodiode Array Detector) fitted with a reverse phase (RP) Thermo Scientific C18 ( $\mathrm{L}=250 \mathrm{~mm}$, I.D $=4.6 \mathrm{~mm}$, and $5 \mu \mathrm{m}$ particles) column. The column temperature was thermostated at $30{ }^{\circ} \mathrm{C}$. The injection volumes were $20 \mu \mathrm{L}$. The mobile phase was a Buffer A (HPLC grade water $+0.1 \%(\mathrm{v} / \mathrm{v})$ trifluoroacetic acid) and Buffer B (HPLC grade acetonitrile $+0.1 \%(\mathrm{v} / \mathrm{v})$ trifluoroacetic acid). The flow-rate was $1 \mathrm{ml} \cdot \mathrm{min}^{-1}$. The eluent gradient started with $10 \%$ of eluent B, gradually increasing to $70 \%$ in $35 \mathrm{~min}$. Eluent B was elevated to $90 \%$ in 5 min and then the system was kept for $5 \mathrm{~min}$, returning to $10 \%$ in $1 \mathrm{~min}$ and equilibrating for $9 \mathrm{~min}$ (return to initial condition and re-equilibrating the column). UV-Detection was performed at $\lambda=255 \mathrm{~nm}$, for substituted benzene structures monitoring. 
The degradation products of AO7 were identified by a LC-MS system. LC-MS system performed with an Alliance e2695 (Waters HPLC pump and autosampler system) and a Quattro-Micro mass spectrometer equipped with an Electrospray (ESI) probe (Waters Micromass, Wythenshawe, Manchester, UK). The detection conditions were : capillary potential of $3.5 \mathrm{kV}$, cone voltage of 30 $\mathrm{V}$, source temperature of $120^{\circ} \mathrm{C}$, desolvation temperature of $450{ }^{\circ} \mathrm{C}$, cone gas flow of $50 \mathrm{l} / \mathrm{h}$, and desolvation gas flow of $450 \mathrm{l} / \mathrm{h}$. Nitrogen was used as nebulizer gas.

A Waters column HSST3 $(\mathrm{L}=100 \mathrm{~mm}$, D.I $=2.1 \mathrm{~mm}$, and $5 \mu \mathrm{m}$ particles) was used for the separation of intermediates. The column was at room temperature $\left(22^{\circ} \mathrm{C}\right)$. The injection volumes were $20 \mu$ l.

The mobile phase was a Buffer A (HPLC grade water $+0.1 \%(\mathrm{v} / \mathrm{v})$ formic acid) and Buffer B (HPLC grade acetonitrile $+0.1 \%(\mathrm{v} / \mathrm{v})$ formic acid). The flow rate was $0.25 \mathrm{~mL} \mathrm{~min}^{-1}$. The eluent gradient started with $10 \%$ of eluent B and was kept for 1 min, gradually increasing to $90 \%$ of B in $2 \mathrm{~min}$ and then the system was kept for $1 \mathrm{~min}$, returning to $10 \%$ in $1 \mathrm{~min}$ and equilibrating for 2 min (return to initial condition and re-equilibrating the column). The eluent from the chromatographic column successively entered in the UV-Vis diode array detector (Waters PDA996) and the ESI interface of the mass spectrometer. MS analysis was performed in positive mode. The mass range was 90 to $400(\mathrm{~m} / \mathrm{z})$.

The eluted components having specific retention time and were characterized by their UV-spectra and/or their mass. The quantification using the standard addition method (HPLC-UV) or external calibration against standard (LC-MS) was performed.

Short-chain acids were identified and quantified by using the HPLC-UV system already described, but fitted with a SHODEX KC 811 (D.I=8 mm, L=300 mm, and $7 \mu \mathrm{m}$ particles) column which was thermostated at $30^{\circ} \mathrm{C}$. UV detection was performed at $\lambda=210 \mathrm{~nm}$. The mobile phase was a Buffer A (HPLC grade water $+0.1 \%(\mathrm{v} / \mathrm{v})$ Phosphoric acid $85 \%)$. The flow rate was $0.50 \mathrm{ml} . \mathrm{min}^{-}$ 1.

\subsubsection{Inorganic Carbon (IC) and Total Organic Carbon (TOC) analysis}

Inorganic ions $\left(\mathrm{NO}_{3}^{-}, \mathrm{NH}_{4}{ }^{+}, \mathrm{SO}_{4}{ }^{2-}\right)$ generated during decomposition of $\mathrm{AO} 7$ were identified by an ion chromatography equipment. In the case of anion, Dionex ICS-1000 system was connected with an AS19 column ( $4 \mathrm{~mm} * 250 \mathrm{~mm}$ ) and the eluent was $\mathrm{KOH}$ which was applied according to the elution gradient: $10 \mathrm{mM}$ in $10 \mathrm{~min}$ then gradient in $20 \mathrm{~min}$ to $45 \mathrm{mM}$. Dionex ICS-900 was used to measure the cation concentration in the treated solution with the column CS12A and eluent of $20 \mathrm{mM}$ methane sulfonic acid. Both columns were thermally controlled at $30{ }^{\circ} \mathrm{C}$, and DS6 conductivity detector was used.

The total organic carbon (TOC) of the initial and treated samples was determined with a TOC-L CSH/CSN Shimadzu (Japan) analyzer. Calibration curves for TOC and IC analysis were built up 
by automatic dilution on the same machine from solutions of TOC standard of $1000 \mathrm{mg} / \mathrm{L}$ and sodium hydrogen carbonate.

\subsubsection{Toxicity tests}

The Microtox ${ }^{\circledR}$ bacteria toxicity test was based on the general principles described by ISO (2007) [24]. The toxicity of $\mathrm{AO} 7$ and its intermediate by-products formed during its degradation was determined by measuring the effect on the luminescence of marine bacteria. Bacterial luminescence was measured using a Microtox ${ }^{\circledR}$ Model 500 Analyzer (Modern Water Inc.; United Kingdom). The bacteria used in this method was the strain Vibrio fischeri NRRL B-11177. This bacterium emitted luminescence during growth relating to cellular respiration which was linked itself to cell activity. As the activity of the cell could be reduced by the presence of toxic elements, bioluminescence is therefore a very good indicator of state of the bacterium and thus of the global toxicity of the sample.

This device allowed for the acute toxicity tests with the help of the software MicrotoxOmni ${ }^{\circledR}$. To identify the relative toxicity of each sample solution, a $81.9 \%$ screening test has been used to characterize the inter-samples toxicity variability: the influence of treatment processes on the effluent toxicity was monitored thanks to a sampling method performed as a function of time. The test performed in this paper is called $81.9 \%$ screening test since all samples have been diluted at $81.9 \%$ of the initial sample concentration by addition of a $22 \% \mathrm{NaCl}$ solution to allow Vibrio fischeri normal activity and thus luminescence emission. Before measuring the bacteria luminescence, $\mathrm{pH}$ of the samples were adjusted between 6.5 and 7.5 by sodium hydroxide or sulfuric acid, then a $0.2 \mu \mathrm{m}$-filtration was performed with syringe filters in order to eliminate any precipitate or solid matter in the solution. The inhibition rate at time $\mathrm{t}: \mathrm{I}(\mathrm{t})$ was calculated thanks to equation (4):

$$
\mathrm{I}(\mathrm{t})(\%)=\left(1-\frac{\mathrm{LU}(\mathrm{t})}{\mathrm{LU}(0)}\right) \cdot 100
$$

Where $L U(t)$ is the intensity of luminescence emitted by bacteria after a $t=5$ min or $t=15$ min of contact with the sample; and $\mathrm{LU}(0)$ : is the initial intensity of luminescence emitted by bacteria before the addition of the sample.

However, in the absence of toxicity, the luminescence of bacteria decreases over time and under the action of environmental conditions. Thus, it is necessary to compensate the errors due to these factors by taking into account the variability of the luminescence $\mathrm{R}(\mathrm{t})$ of the bacteria in a control solution (MilliQ water and $\mathrm{NaCl}$ ) which gives the $\mathrm{LU}_{0}$ values. Equation (5) gives the corrected term $\mathrm{R}(\mathrm{t})$.

$$
R(t)=\frac{\mathrm{LU} 0(\mathrm{t})}{\mathrm{LU} 0(0)}
$$

Where LU0(t) is the intensity of luminescence emitted by bacteria after a $t=5$ min or $t=15$ min of contact with the control solution (MilliQ water and $\mathrm{NaCl}$ ); and $\mathrm{LU} 0(0)$ : is the initial intensity of 
luminescence emitted by bacteria before the addition of the control solution (MilliQ water and $\mathrm{NaCl})$.

Then the corrected inhibition rate at time $\mathrm{t}$ : $\mathrm{Ic}(\mathrm{t})$ intrinsically attributable to the sample toxicity is calculated using equation (6). In the rest of this paper, Ic(t) is called "Inhibition" and is expressed in $\%$.

$$
\operatorname{Ic}(\mathrm{t})(\%)=\left(1-\frac{\mathrm{LU}(\mathrm{t})}{R(t) \cdot \mathrm{LU}(0)}\right) \cdot 100
$$

Furthermore, eco-toxicity tests were carried out on the commercially available by-products in order to confirm or not the toxicity of the compounds formed during the degradation of the main molecule: acid orange 7 (AO7). These by-products and their mixtures were prepared with the maximum concentrations detected by HPLC-UV analysis during the Electro-Fenton experiment.

\section{Results and discussion}

\subsection{Effect of applied current on the degradation kinetics}

In the Electro-Fenton process, the applied current is an important parameter for both operational cost and process efficiency [25]. To evaluate the effect of applied current on the decomposition kinetics of $\mathrm{AO} 7$, different current densities were investigated as follows: at -1, -1.7, -5, -8.3, and $11.7 \mathrm{~mA} \mathrm{~cm}^{-2}$, corresponding to $60,100,300,500$ and $700 \mathrm{~mA}$. Figure $3 \mathrm{a}$ indicated that the decomposition rate increased rapidly with the rise of cathodic current from $-1 \mathrm{~mA} . \mathrm{cm}^{-2}$ to $-8.3 \mathrm{~mA}$ $\mathrm{cm}^{-2}$. However, from applied current density values of $-8.3 \mathrm{~mA} \mathrm{~cm}$, the degradation nearly kept stable and complete color removal of dye solution could be reached after only $3 \mathrm{~min}$. Therefore this value corresponds to the optimal current density which allows optimal $\mathrm{H}_{2} \mathrm{O}_{2}$ production and thereby hydroxyl radical generation, while avoiding competitive side-reactions such as $\mathrm{H}_{2} \mathrm{O}$ production (equation 7), proton reductions or $\mathrm{H}_{2} \mathrm{O}_{2}$ decomposition at cathode (equations 8 and 9).

$$
\begin{aligned}
& \mathrm{O}_{2}+4 \mathrm{H}^{+}+4 \mathrm{e}^{-} \rightarrow 2 \mathrm{H}_{2} \mathrm{O} \\
& 2 \mathrm{H}^{+}+2 \mathrm{e}^{-} \rightarrow \mathrm{H}_{2} \\
& \mathrm{H}_{2} \mathrm{O}_{2}+2 \mathrm{H}^{+}+2 \mathrm{e}^{-} \rightarrow 2 \mathrm{H}_{2} \mathrm{O}
\end{aligned}
$$



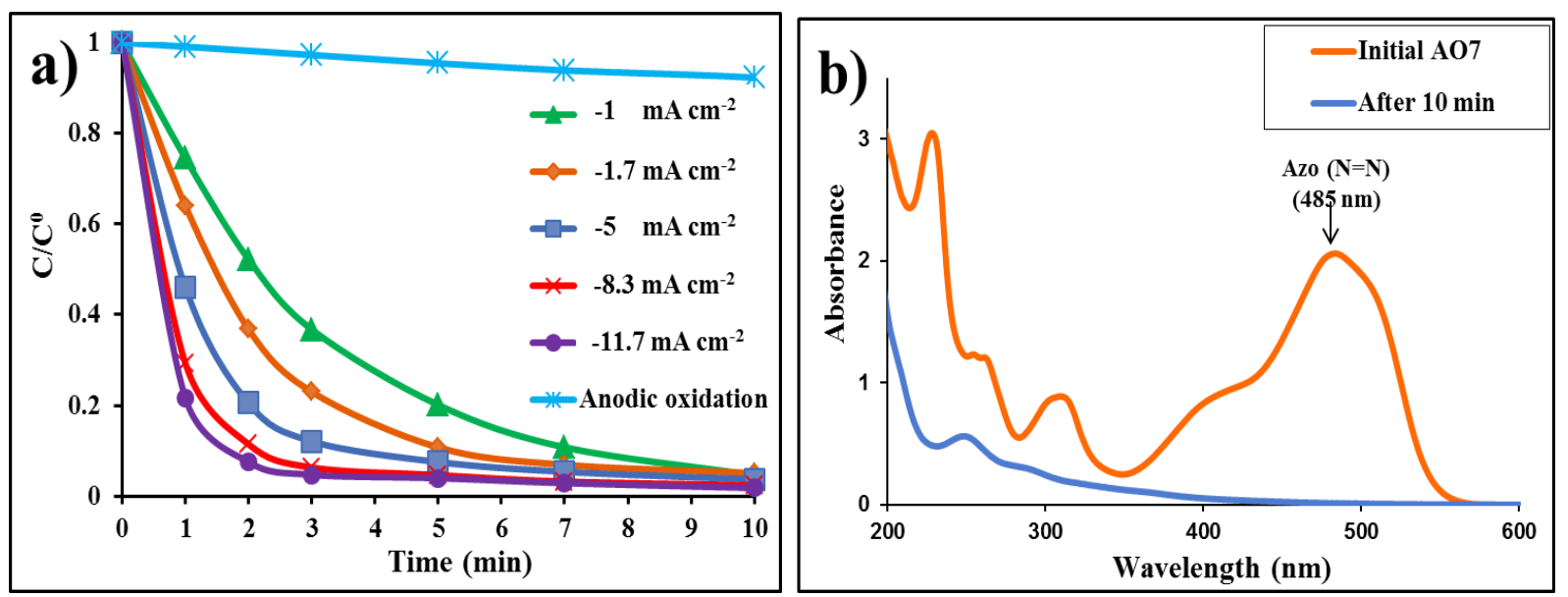

Figure 3. (a) Degradation kinetics of AO7 determined at $485 \mathrm{~nm}$ (RSD: $2 \%(\mathrm{n}=3)$ ) by the EF process on carbon felt cathode $\left(60 \mathrm{~cm}^{2}\right)$ at operating conditions: $200 \mathrm{~mL} \mathrm{AO} 7(0.1 \mathrm{mM})$ aqueous solution in $50 \mathrm{mM} \mathrm{Na}_{2} \mathrm{SO}_{4}$ with $0.2 \mathrm{mM}$ $\mathrm{Fe}^{2+}$ of $\mathrm{pH} 3.0$, Pt anode, and different constant current densities applied. (b) The absorption spectrum of initial AO7 and treated solution after $10 \mathrm{~min}$.

It could be seen from Figure $3 \mathrm{~b}$ that absorption band related to azo bond (wavelength at $485 \mathrm{~nm}$ ) disappeared totally after 10 minutes of treatment. The absorption bands at 228, 254 and $310 \mathrm{~nm}$ present in the initial solution disappeared rapidly which is characteristics of aromatic ring structure decomposition into various intermediate sub-products before mineralization. As demonstrated in a previous work [22], the hydroxyl radicals could also be created from the oxidation of water on the anode surface according to equation (10). However, the degradation of AO7 by this anodic oxidation process was very weak, compared to Electro-Fenton process: after 3 min of oxidation process applied, there was only $2.6 \%$ of $0.1 \mathrm{mM} \mathrm{AO} 7$ degradation at anode (Figure 3a) which implies that this process contributed to a very small extent to the overall degradation of AO7 by EF process. In the present study, we will therefore not consider the influence of the anodic oxidation.

$$
\mathrm{H}_{2} \mathrm{O} \rightarrow \mathrm{Pt}(\cdot \mathrm{OH})+\mathrm{H}^{+}+\mathrm{e}^{-}
$$

\subsection{Effect of catalyst concentration on the mineralization efficiency}

As it can be seen from Figure 4, the mineralization rate increased with increasing $\mathrm{Fe}^{2+}$ concentration from 0.05 to $0.2 \mathrm{mM}$, because the higher catalyst concentration, the higher production of hydroxyl radicals at cathode. However, for larger concentrations of catalyst tested (from 1 to $2 \mathrm{mM}$ ), a decline in the TOC removal was observed. This is characteristics of a sidereaction taking place between the excess of hydroxyl radical produced and iron species, as mentioned in previous studies dealing with EF process [26,27]. Therefore, $0.2 \mathrm{mM}$ of catalyst was chosen as the optimal concentration to be used to degrade AO7. After 120 min treatment, almost $90 \%$ of organic compounds in the initial AO7 solution $(0.1 \mathrm{mM})$ were eliminated. The fast degradation of $\mathrm{AO} 7$ at the early stage of electrolysis originated from the easy break of azo bond 
and rapid decomposition of the intermediate naphthalene-type compounds formed, such as 2naphtol; 2-hydro-1,4 naphthoquinone; and 1,4-benzoquinone (Figure 5 a, b).

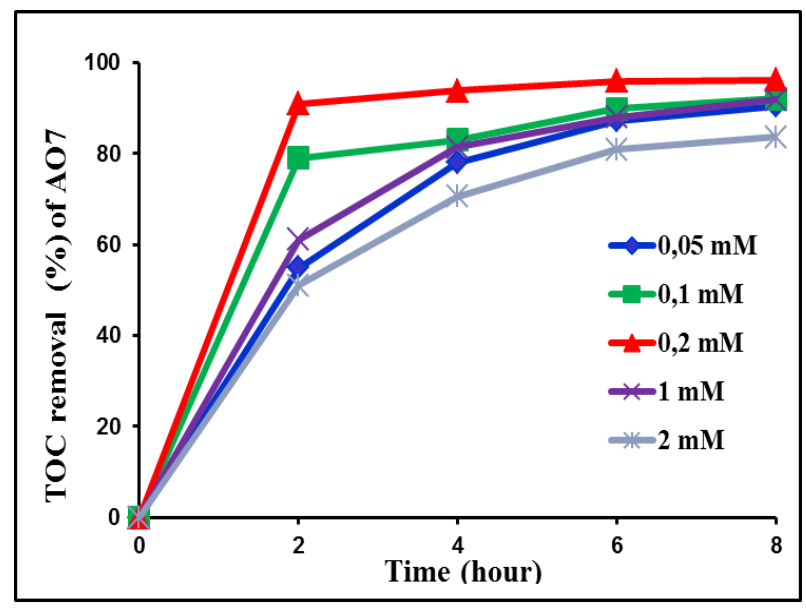

Figure 4. TOC removal after $8 \mathrm{~h}$ treatment of $200 \mathrm{~mL}$ AO7 $(0.1 \mathrm{mM}) ; \mathrm{pH}=3$; $\left[\mathrm{Na}_{2} \mathrm{SO}_{4}\right]=50 \mathrm{mM}, \mathrm{I}=-8.3 \mathrm{~mA} \mathrm{~cm}^{-2}$ for different $\mathrm{Fe}^{2+}$ catalyst concentrations between $0.05 \mathrm{mM}$ and $2 \mathrm{mM}$. (RSD: $2 \%(\mathrm{n}=3)$ )

\subsection{Degradation pathway of Acid Orange 7 during EF process}

The construction of the degradation pathways to identify the possible molecular structure of byproducts was performed according to the following steps:

(i) Many of AO7 by-products formed in our EF samples had already been identified in previous studies: This was the case of 1,4 benzoquinone (BZQ); 4-hydroxybenzenesulfonic acid (HBA); 2-naphtol (NOL); 2-hydroxy-1,4 naphthoquinone (HNQ); 1,2-naphthoquinone (NAPQ); 2-formyl-benzoic acid (FBA) and hydroquinone (HQ) and other short chain carboxylic acids. For these compounds, we could therefore compare HPLC-UV chromatograms of EF samples with individual chromatograms of the corresponding standard by-products which have been purchased and analyzed in LC-MS and HPLC-UV. The comparison of retention times enabled the by-product identification in EF samples. Then, standard addition method applied to our EF samples allowed by-product quantitative analyses.

(ii) The other AO7 by-products detected in HPLC-UV chromatograms but that could not be identified in the first step (i) were analysed by LC-MS in order to qualify their molecular structures from the mass spectroscopic signals. They concerned the following molecules: 2,3Dihydroxy-1,4-naphthalenedione, 1,2-naphthalenediol, 1(3H)-isobenzofuranone, 4-[(2,3dihydroxy-1-naphthyl)diazenly]-benzenesulfonate, $\quad$ 4-[(2,3,4-trihydroxy-1-naphthyl)diazenly]benzenesulfonate.

\subsubsection{Evolution of aromatic compounds}

The decomposition of AO7 by EF process led to the formation of various aromatic compounds, short-chain carboxylic acids and inorganic ions, as shown in Figure 5. To identify these products, $500 \mathrm{~mL}$ of $1 \mathrm{mM} \mathrm{AO} 7$ was electrolyzed with an applied current of $-8.3 \mathrm{~mA} \cdot \mathrm{cm}^{-2}$ and $0.2 \mathrm{mM}$ of 
catalyst. Degradation by-products except inorganic ions which were formed during the ElectroFenton process were analyzed by HPLC-UV and LC/MS (Table 1) as described in section 2.3. It was noticed that aromatic intermediates were already detected at a very short reaction time after only 2 minutes of treatment. AO7 drastically decreased from the first few minutes before complete removal in 20 minutes, while the concentration of 1,4 benzoquinone (BZQ), 4hydroxybenzenesulfonic acid (HBA), 2-naphtol (NOL), 2-hydro-1,4 naphthoquinone (HNQ) and 1,2-naphthoquinone (NAPQ) increased and reached maximum values of $0.0037 \mathrm{mM}, 0.0075 \mathrm{mM}$, $0.012 \mathrm{mM}, 0.17 \mathrm{mM}$ and $0.32 \mathrm{mM}$, respectively, before being totally degraded after $80 \mathrm{~min}$. The predominant aromatic product from the degradation of AO7 was 2-formyl-benzoic acid (FBA) and hydroquinone (HQ). Their formation was delayed compared to the others and attained the highest concentration at $0.854 \mathrm{mM}$ for HQ and $0.94 \mathrm{mM}$ for FBA in 14 and 40 minutes respectively before completely being removed after 80 and $180 \mathrm{~min}$. From LC/MS analysis, some other aromatic compounds could be identified such as 2,3-Dihydroxy-1,4-naphthalenedione, 1,2naphthalenediol, 1(3H)-isobenzofuranone, 4-[(2,3-dihydroxy-1-naphthyl)diazenyl]benzenesulfonate, 4-[(2,3,4-trihydroxy-1-naphthyl)diazenyl]-benzenesulfonate between 10 and 20 min. of treatment. The by-products, their occurrence time and their maximum concentrations are listed in Table 1. Also, the evolution of their concentration as a function of time can be shown in Figure 5.

Table 1. List of AO7 by-products and their concentrations during Electro-Fenton experiment.

\begin{tabular}{|c|c|c|c|}
\hline \multicolumn{2}{|c|}{ Aromatic by-products } & \multicolumn{2}{|c|}{ Short-chain carboxylic acids } \\
\hline $\begin{array}{c}\text { By-products and their occurrence } \\
\text { period }\end{array}$ & $\begin{array}{c}\text { Maximum } \\
\text { concentrations }\end{array}$ & $\begin{array}{l}\text { By-products and } \\
\text { their occurrence } \\
\text { period }\end{array}$ & $\begin{array}{c}\text { Maximum } \\
\text { concentrations }\end{array}$ \\
\hline $\begin{array}{l}\cdot \text { Hydroquinone } \\
\text { (35-60min) }\end{array}$ & $0.854 \mathrm{mM}$ & $\begin{array}{l}\text { - Oxalic acid } \\
(360-450 \mathrm{~min})\end{array}$ & $1.114 \mathrm{mM}$ \\
\hline $\begin{array}{l}\cdot 1,4 \text {-Benzoquinone } \\
(12-16 \mathrm{~min})\end{array}$ & $0.0037 \mathrm{mM}$ & $\begin{array}{l}\cdot \text { Maleic acid } \\
(450-480 \mathrm{~min})\end{array}$ & $0.173 \mathrm{mM}$ \\
\hline $\begin{array}{l}\text {-2-Formyl-benzoic acid } \\
\text { (14-18min) }\end{array}$ & $0.94 \mathrm{mM}$ & $\begin{array}{l}\cdot \text { Oxamic acid } \\
\text { (450-480min) }\end{array}$ & $0.091 \mathrm{mM}$ \\
\hline $\begin{array}{l}\cdot \text { 1,2-Napthoquinone } \\
\text { (6-16min) }\end{array}$ & $0.32 \mathrm{mM}$ & $\begin{array}{l}\text { - Fumaric acid } \\
\text { (5-30min) }\end{array}$ & $0.254 \mathrm{mM}$ \\
\hline $\begin{array}{l}\text {-2-Hydroxyl-1,4-napthalenedione } \\
\text { (16-28min) }\end{array}$ & $0.17 \mathrm{mM}$ & & \\
\hline $\begin{array}{l}\text { - 4-Hydroxylbenzenesulphonic } \\
\text { acid (10-16min) }\end{array}$ & $0.0075 \mathrm{mM}$ & & \\
\hline - 2-Napthol (28-35min) & 0.12 & & \\
\hline
\end{tabular}




\subsubsection{Evolution of short-chain carboxylic acids}

Generation of short-chain carboxylic acids was expected from the oxidative ring opening of aromatic intermediates [28-31]. Actually, during the degradation of AO7 (1mM), the oxalic, the maleic, the oxamic and the fumaric acids could be detected by HPLC at 11.6, 13.59, 15.23 and 23.54 minutes of retention time respectively. Figure $5 \mathrm{c}$ showed their evolution as a function of EF treatment time during the decomposition of $1 \mathrm{mM} \mathrm{AO7}$ aqueous solution at $\mathrm{pH}$ 3.0. Generally, these acids were generated in very short time of reaction. In the early period of AO7 decomposition, fumaric acid (FA) was the main short-chain by-product which appeared as soon as the electrolysis started (after 5 minutes of reaction). It was then destroyed quickly into shorter chain acids such as oxalic and maleic acids. Oxalic, maleic and oxamic acids were only detected after $4 \mathrm{~h}$ of reaction. This meant that they were typical degradation products from aromatic compounds and fumaric acid. Oxalic acid (OA) was the main final by-product formed before complete mineralization, as also observed during treatments carried out by advanced oxidation techniques [32-35]. Oxamic acid (OMA) could be produced from the degradation of 2-hydroxy-4(N-acetyl)aminophenol or from the oxidation of acetamide [36]. Maleic acid was detected, but at a very low concentration which is in accordance with what has been reported by Ozcan et al. [37]. After $8 \mathrm{~h}$ treatment, the concentration of oxalic and maleic acids were measured at $0.883 \mathrm{mM}$ and $0.173 \mathrm{mM}$ respectively. At this time, $83.24 \mathrm{mg} \mathrm{L}^{-1}$ of TOC was removed, decreasing to $58 \%$ of the initial AO7 solution.

\subsubsection{Evolution of inorganic ions}

The conversion of original nitrogen and sulfur elements from degradation of AO7 dye led to the formation of inorganic ions such as sulfate, nitrate and ammonium which is presented in Figure 5d. Sulfate ion apparition was observed quickly, indeed after $1 \mathrm{~h}$ of oxidation treatment its concentration attained around $1 \mathrm{mM}$ which was in good agreement with molar balance with regard to the initial concentration of sulfur elements. In a different way, ammonium ion was generated in small amount during all process. As also seen in Figure 5d, nitrate ion concentration increases linearly with the treatment duration and reached the value of $1.1 \mathrm{mM}$ after $8 \mathrm{~h}$. There was no equilibration of the nitrogen molar balance which could be explained by the fact that nitrogen could be transferred to the gas phase via $\mathrm{N}_{2}$ and $\mathrm{NH}_{3}$ apparition which have already been observed in previous studies [25]. 

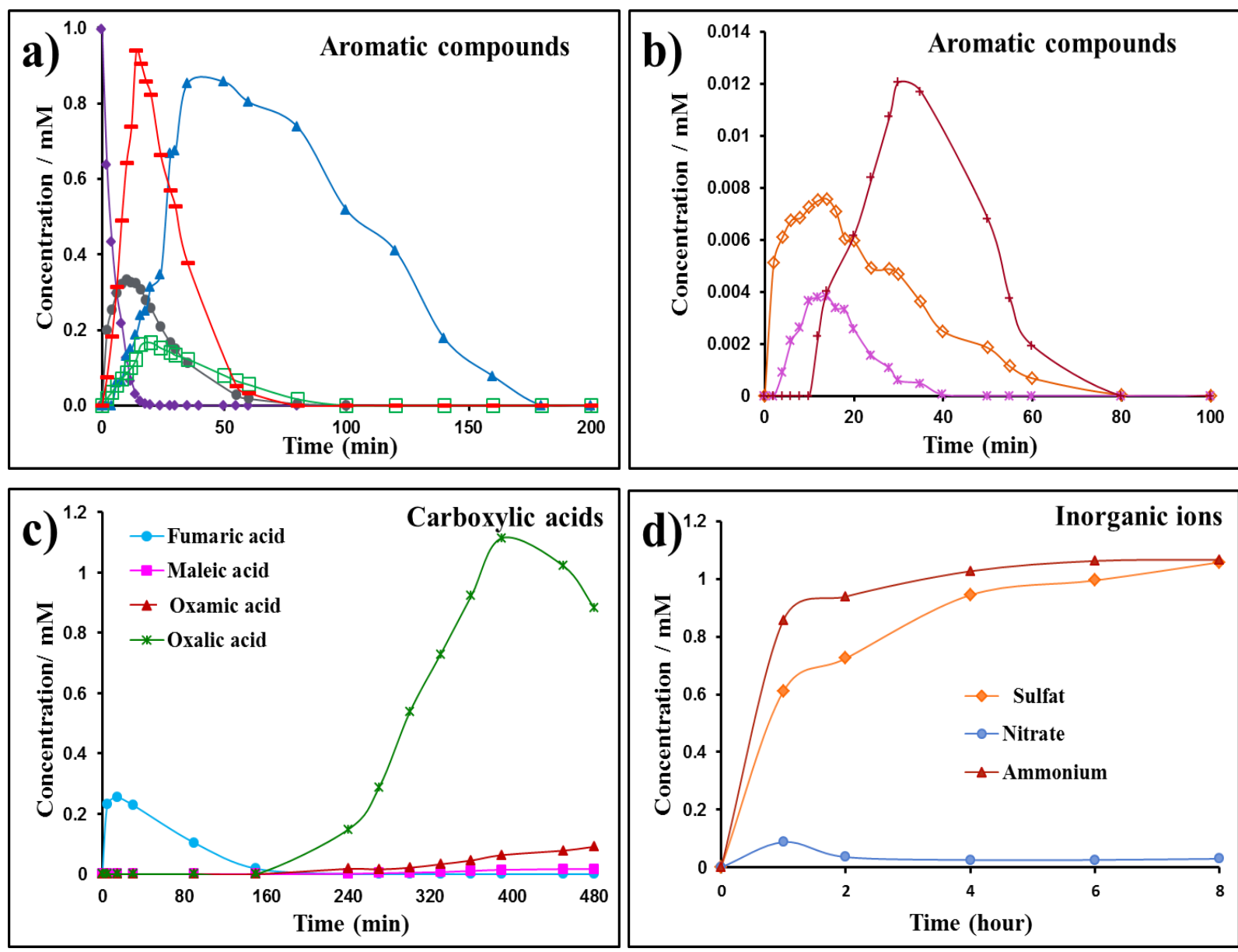

Figure 5. (a, b) Time-course of AO7 and the aromatic degradations (RSD 2\% n=3): AO7 ( $\bullet$ ); 1,2 naphthoquinone

$(\bigcirc)$; Hydroquinone $(\Delta)$; 4-hydroxybenzenesulfonic acid $(\diamond)$; 1,4 benzoquinone ( $*$ ); 2-naphtol (+); 2-hydro-1,4 naphthoquinone ( $\square$ ), 2-formyl-benzoic acid (-); (c) Carboxylic acids (RSD 2\% n=3); (d) Inorganic ions (RSD 5\% $\mathrm{n}=3$ ) during EF treatment of $500 \mathrm{~mL} \mathrm{AO} 7$ at $\mathrm{C}_{0}=1.0 \mathrm{mM} ; \mathrm{pH}=3 ;\left[\mathrm{Na}_{2} \mathrm{SO}_{4}\right]=50 \mathrm{mM}, \mathrm{I}=-8.3 \mathrm{~mA} \cdot \mathrm{cm}^{-2}, \mathrm{and}^{2+}\left[\mathrm{Fe}^{2+}\right]=$ $0.2 \mathrm{mM}$.

\subsubsection{Toxicity assessment during AO7 degradation}

Figure 6 presented toxicity assessments during AO7 oxidation by EF process (with two different operating conditions: $200 \mathrm{~mL}$ of $0.1 \mathrm{mM} \mathrm{AO7}$ in Figure 6a and $500 \mathrm{~mL}$ of $1 \mathrm{mM} \mathrm{AO} 7$ in Figure 6b). Toxicity was measured by monitoring the inhibition of marine bacteria Vibrio fischeri after 5 min and 15 min of exposure. When the EF process started, luminescence inhibition which reflects solution toxicity immediately increased up to $100 \%$ and remained at this value during 20 minutes for $200 \mathrm{~mL}$ of $0.1 \mathrm{mM} \mathrm{AO} 7$ and 100 minutes for $500 \mathrm{~mL}$ of $1 \mathrm{mM} \mathrm{AO}$. This could be linked to the formation of very toxic compounds like 2-naphtol (NOL); 2-hydro-1,4 naphthoquinone (HNQ); 1,2-naphthoquinone (NAPQ) and 1,4-benzoquinone (BZQ) (Figure 5a), as already shown by other studies [38-42]. After that, the decomposition of these products and the emergence of short-chain carboxylic acids led to the detoxification of the solution, as confirmed by the inhibition ratio evolution, which decreased quickly to zero after $80 \mathrm{~min}$ and $270 \mathrm{~min}$ for $200 \mathrm{~mL}$ of $0.1 \mathrm{mM} \mathrm{AO} 7$ and $500 \mathrm{~mL}$ of $1 \mathrm{mM} \mathrm{AO7}$ respectively. These results demonstrated that the solution toxicity is closely linked to the presence of aromatic compounds (AO7 and its by- 
products) at the early stage of EF process, unlike short-chain carboxylic acids found at the end of electrolysis (such as maleic acid) which have a very low toxicity.
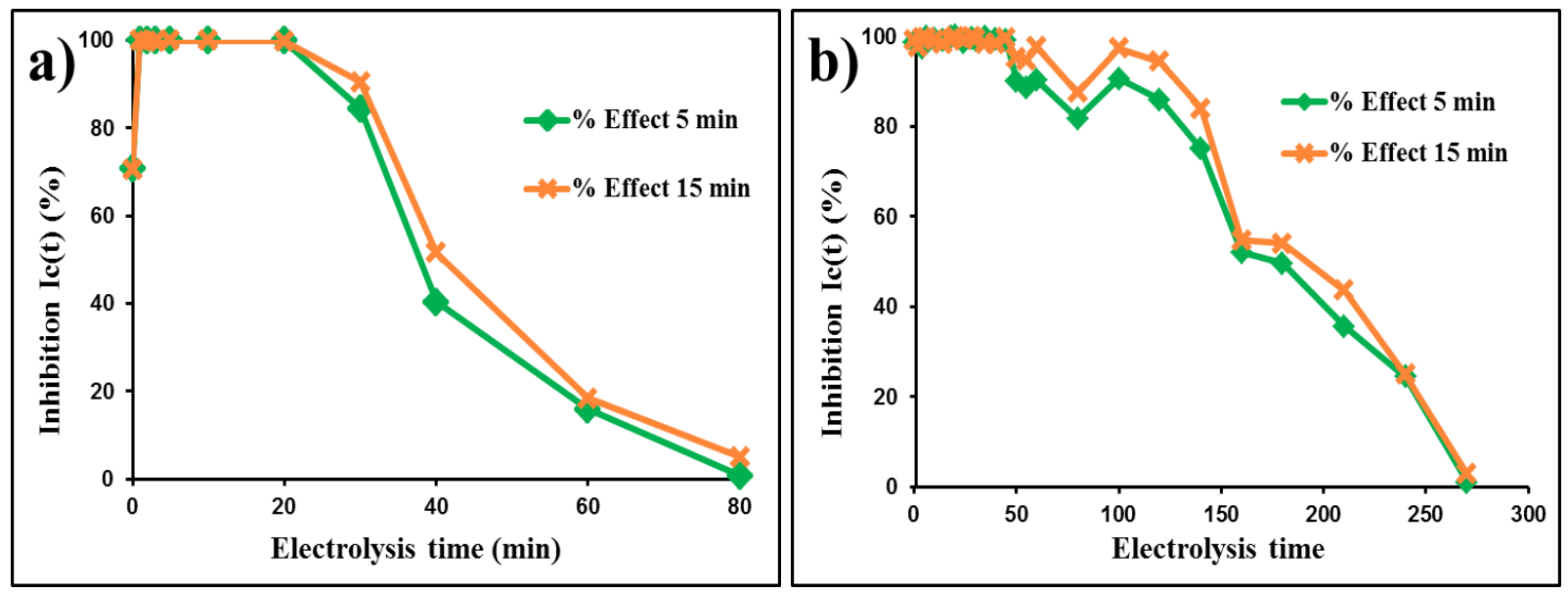

Figure 6. Evolution of the inhibition of marine bacteria luminescence after 5 min and 15 min of exposure with a sample taken after different EF treatment duration of (a) $200 \mathrm{~mL}$ of $0.1 \mathrm{mM} \mathrm{AO} 7$ and (b) $500 \mathrm{~mL}$ of $1 \mathrm{mM} \mathrm{AO} 7$ at pH $=3 ;\left[\mathrm{Na}_{2} \mathrm{SO}_{4}\right]=50 \mathrm{mM}, \mathrm{I}=-8.3 \mathrm{~mA} \cdot \mathrm{cm}^{-2}$, and $\left[\mathrm{Fe}^{2+}\right]=0.2 \mathrm{mM} \cdot \mathrm{RSD}(\mathrm{n}=5): 12 \%$ for inhibition $<20 \% ; 5 \%$ for $20 \%$ $<$ inhibition $<70 \%$ and $0 \%$ for inhibition $>70 \%$

After that, the toxicity of each by-product was measured individually at the maximum concentration using HPLC analysis (Table 1). It can be seen from Figure 7a that during the analysis time from of 5 to $30 \mathrm{~min}, 1$,4-benzoquinone (BZQ) and 1,2-napthoquinone (NAPQ) had the highest toxicity around $100 \%$ compared to $70.43 \%$ for 2 -formyl-benzoic acid (FBA) or $45.56 \%$ for 2-hydroxyl-1,4-naphthalenedione (HNQ). This observation confirms the results found in literature about the toxicity of aromatic hydrocarbons [43]. This result also proved that 1,4benzoquinone has a strong eco-toxicological impact. Indeed, a small amount formed of only $0.0037 \mathrm{mM}$ caused a noticeable toxic virulence on the selected strain of bacteria. On the opposite, 4-hydroxylbenzenesulfonic acid (HBA) did not contribute for the toxicity of the oxidized solution when its value was less than 5\%. In the following period between 30 and 60 min (Figure $7 \mathrm{~b}$ ), the appearance of hydroquinone with the maximum concentration of $0.9 \mathrm{mM}$ led to very high toxicity for the solution. Although, remaining at a low amount, around $0.012 \mathrm{mM}, 2$-napthol (NOL) presented a remarkable toxicity of $86 \%$. At the end of the experiment, between $6 \mathrm{~h}$ and $8 \mathrm{~h}$ (Figure $7 \mathrm{c}$ ), almost all aromatic compounds were transformed into carboxylic acids like oxalic acid (OA), oxamic acid (OMA) which present a relatively low toxicity. 

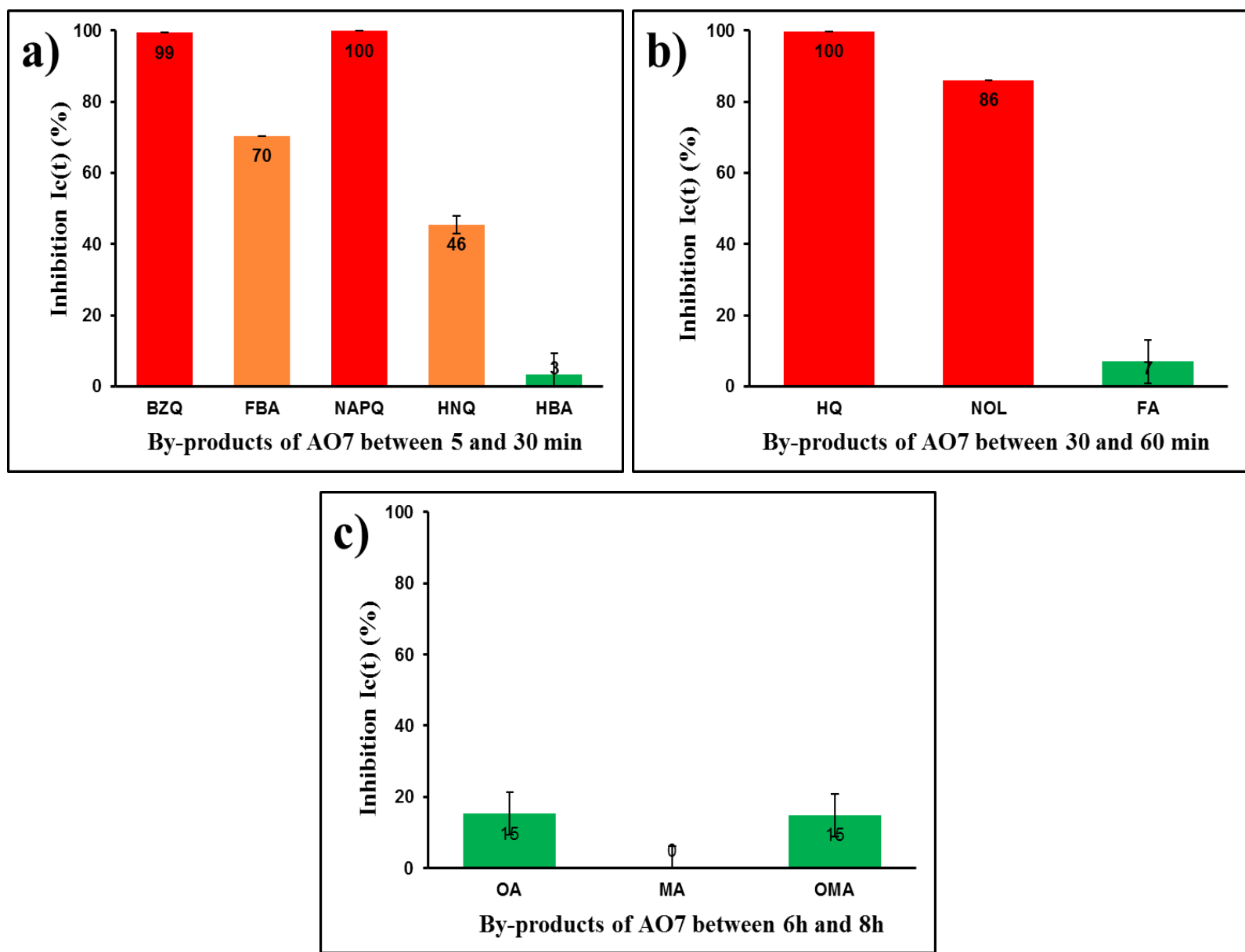

Figure 7. Toxicity of AO7 by-products appearing between (a) 5 and 30 min with $\mathrm{BZQ}=1$,4-benzoquinone, FBA = 2formyl-benzoic acid, NAPQ = 1,2-napthoquinone, HNQ = 2-hydroxyl-1,4-naphthalenedione, HBA = 4hydroxylbenzenesulfonic acid; (b) 30 and $60 \mathrm{~min}$ with $\mathrm{HQ}=$ hydroquinone, NOL = 2-naphthol, FA= fumaric acid, $\mathrm{OA}=$ oxalic acid, $\mathrm{MA}=$ maleic acid, $\mathrm{OMA}=$ Oxamic acid and (c) $6 \mathrm{~h}$ and $8 \mathrm{~h}$ of EF treatment of $500 \mathrm{~mL}(1 \mathrm{mM} \mathrm{AO7})$ at $\mathrm{pH}=3 ;\left[\mathrm{Na}_{2} \mathrm{SO}_{4}\right]=50 \mathrm{mM}, \mathrm{I}=-8.3 \mathrm{~mA} \cdot \mathrm{cm}^{-2}$, and $\left[\mathrm{Fe}^{2+}\right]=0.2 \mathrm{mM}$.

To understand well about the toxicity of oxidized solution, AO7 by-products were mixed together at their highest concentrations and the resulting toxicity of the different combinations was measured. Figure 8a, b, c and d shows the toxicity of by-products between 5 and 30 min of EF process which corresponds to the combination of 2, 3, 4, 5 or 6 kinds of compounds identified during this period. Because of high toxicity of 1,4-benzoquinone (BZQ), most of its mixtures with the five other compounds were found to be highly toxic for the marine bacteria. Therefore, the toxicity of these groups was huge, around 100\%, while the mixtures which included 2-hydroxyl1,4-napthalenedione (HNQ), 4-hydroxylbenzenesulphonic acid (HBA) or fumaric acid (FA) did not induce a significant increase of the solution toxicity. The second set of mixtures for AO7 byproducts observed between 30 and $60 \mathrm{~min}$ of EF process (Figure 8e) were also found to be toxic, except the one with 2-naphthol and fumaric acid as its value was approximately $40 \%$. In agreement with the assessments of individual compounds toxicity and mixture tests, the last mixtures done with compounds observed between $6 \mathrm{~h}$ and $8 \mathrm{~h}$ of EF process (Figure $8 \mathrm{f}$ ) did not show a valuable toxicity. As a result, it could be concluded that the oxidized AO7 solution toxicity was mainly caused by aromatic compounds which appeared during the first minutes of the 
degradation process. Then, the attack of hydroxyl radical $\bullet \mathrm{OH}$ produced by Electron-Fenton reaction produced short-chain carboxylic acids which declined importantly the toxicity and lead to a less harmful solution for marine bacteria. These results give out a full picture about toxic combined interactions of $\mathrm{AO} 7$ by-products formed during EF oxidation in aqueous medium which could be very useful and interesting for environmental applications of this advanced oxidation process.
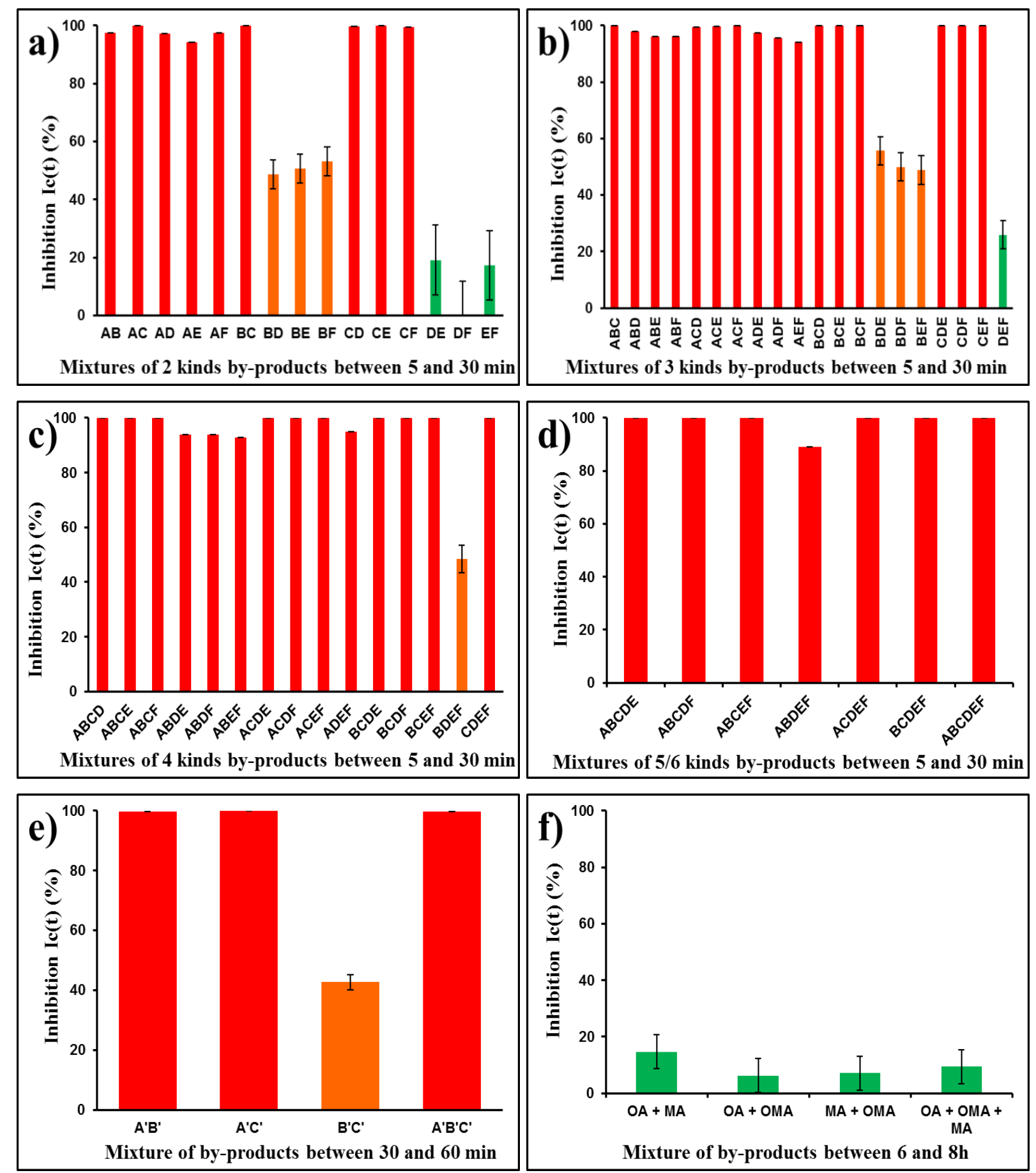

Figure 8. Toxicity of mixtures of (a) 2 kinds, (b) 3 kinds, (c) 4 kinds, (d) 5 or 6 kinds of by-products found between 5 and $30 \mathrm{~min}$; (e) between 30 and $60 \mathrm{~min}$ and (f) for $6 \mathrm{~h}$ and $8 \mathrm{~h}$ of EF process of AO7 at following operating conditions: $500 \mathrm{~mL}(1 \mathrm{mM} \mathrm{AO})$ at $\mathrm{pH}=3 ;\left[\mathrm{Na}_{2} \mathrm{SO}_{4}\right]=50 \mathrm{mM}, \mathrm{I}=-8.3 \mathrm{~mA} \cdot \mathrm{cm}^{-2},\left[\mathrm{Fe}^{2+}\right]=0.2 \mathrm{mM} . \mathrm{A}=\mathrm{BZQ}, \mathrm{B}=$ $\mathrm{FBA}, \mathrm{C}=\mathrm{NAPQ}, \mathrm{D}=\mathrm{HNQ}, \mathrm{E}=\mathrm{HBA}, \mathrm{F}=\mathrm{FA} ; \mathrm{A}^{\prime}=\mathrm{HQ}, \mathrm{B}^{\prime}=\mathrm{NOL}$, and $\mathrm{C}^{\prime}=\mathrm{FA}$. 


\subsubsection{Degradation pathway of AO7 solution}

From the identification of by-products by HPLC-UV and LC-MS methods (Table 2), a possible pathway for AO7 dye degradation by the electro-Fenton process is proposed in Figure 9. The process was initiated by ${ }^{\bullet} \mathrm{OH}$ radical attack resulting in the formation of two hydroxylated AO7 molecules, i.e. 4-[(2,3-dihydroxy-1-naphthyl)diazenly]-benzenesulfonate $(\mathrm{m} / \mathrm{z}=346)(\mathrm{XI})$ and 4[(2,3,4-trihydroxy-1-naphthyl)diazenly]-benzenesulfonate $(\mathrm{m} / \mathrm{z}=362)$ (XII) which were identified within the first minutes of the EF reaction. These hydroxylated intermediates were rarely seen in other previous study dealing with the degradation of AO7 dye. The formation of those intermediates has however been reported during the photocatalytic degradation of azo dye in aqueous $\mathrm{TiO}_{2}$ solution [44]. Then, the process continued with the ${ }^{\bullet} \mathrm{OH}$ radical attack of azo bond to form the following intermediates: 1,2-naphthoquinone (IV) and 4-hydroxybenzensulfonic acid (VI). Afterwards, 4-hydroxylbenzenesulfonic acid underwent further desulfonation to form 1,4benzoquinone (II ) that was then oxidized to hydroxylated hydroquinone (I) and suggested 1,2,4benzentriol. Actually, the latter product could be hardly identified because it was unstable and quickly transformed into carboxylic acids by oxidative ring opening reactions. Intermediate (IV) was oxidized to form well identified naphthalene-type compounds, such as 2-hydroxy-1,4naphthalenedione (V), 2,3-dihydroxy-1,4-naphthalenedione (VIII), 1,2-naphthalenediol (IX) and 2-naphthol (VII). The formation of these naphthalene-type products was also been reported in several previous studies dealing with AO7 degradation $[45,46]$. By continuous ${ }^{\bullet} \mathrm{OH}$ radical action, naphthalene by-products were decomposed into 1(3H)-isobenzofuranone $(\mathrm{X})$ and 2-formylbenzoic acid (III). These last aromatic by-products were further degraded to generate short-chain carboxylic acids including fumaric acid, maleic acid, oxalic acid and oxamic acid. Finally, these organic acids were decomposed into $\mathrm{CO}_{2}, \mathrm{H}_{2} \mathrm{O}$ and inorganic ions. 


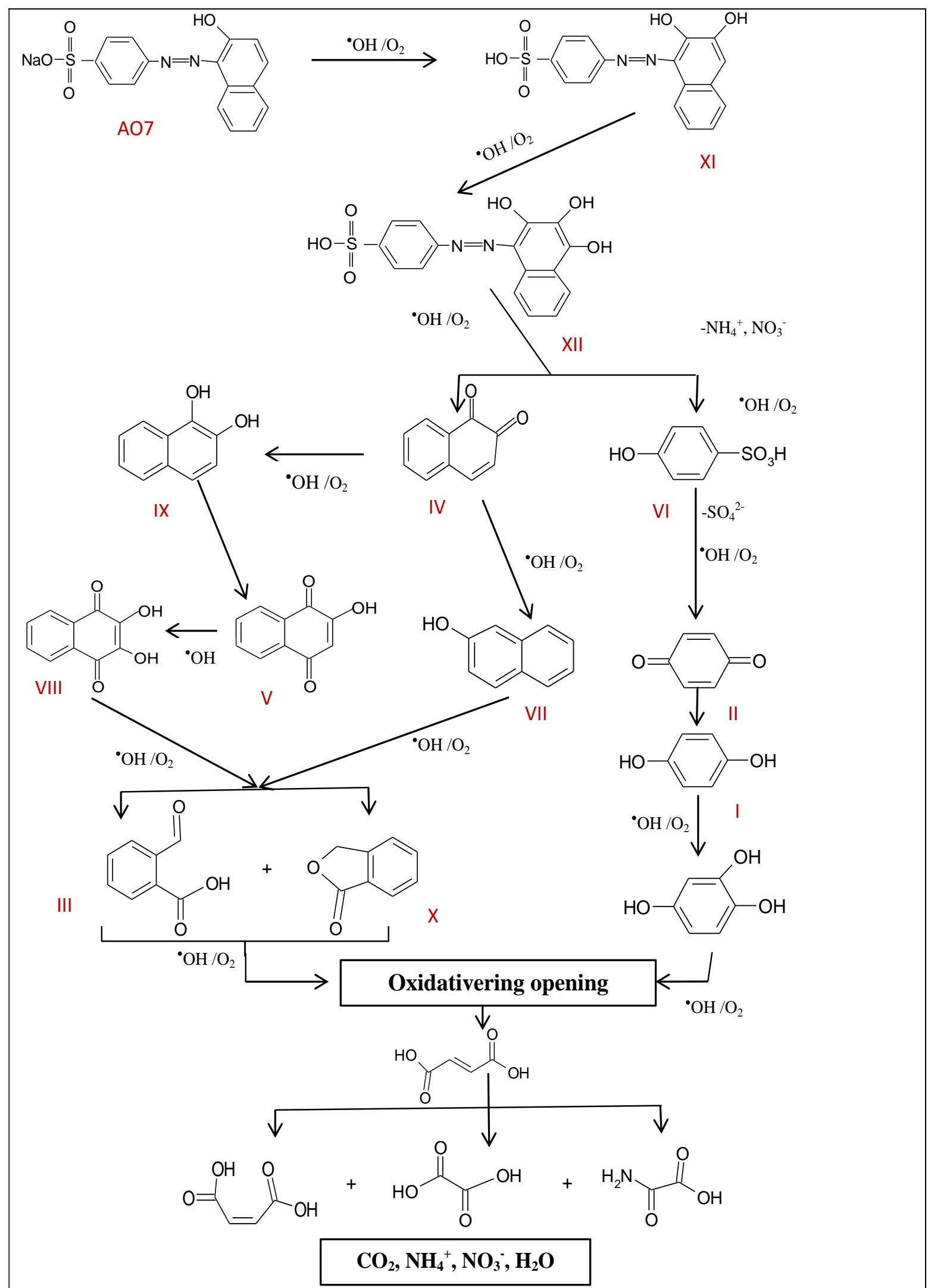

Figure 9. General reaction sequence proposed for Acid Orange 7 (AO7) mineralization in acid medium by hydroxyl radicals during $\mathrm{EF}$ process. 
Table2. HPLC and LC/MS identification parameters (retention times $\left(t_{R}\right)$ ), MS mass fragmentation) of aromatic by-products formed during the Electro-Fenton treatment of AO7.

\begin{tabular}{|c|c|c|c|c|}
\hline \multirow[t]{2}{*}{ No } & \multirow{2}{*}{ Compound name } & $\begin{array}{l}\text { HPLC- } \\
\text { UV }\end{array}$ & \multicolumn{2}{|r|}{ LC-MS } \\
\hline & & $\operatorname{tr}(\min )$ & $t_{R}(\min )$ & $\begin{array}{l}\text { Molecular mass }\left(\mathrm{MH}^{+}\right) \\
\text {and fragments }\end{array}$ \\
\hline $\mathrm{I}$ & Hydroquinone & 5.08 & & \\
\hline II & 1,4-Benzoquinone & 6.52 & & \\
\hline III & 2-Formyl-benzoic acid & 9.44 & 1.87 & $149,118,96$ \\
\hline IV & 1,2-Naphthoquinone & 17.39 & & \\
\hline $\mathrm{V}$ & 2-Hydroxyl-1,4-naphthalenedione & 18.71 & 3.82 & $175,147,118$ \\
\hline VI & 4-Hydroxylbenzenesulfonic acid & 19.33 & 4.09 & $174,158,130,97$ \\
\hline VII & 2-Naphthol & 27.11 & 4.64 & 147,91 \\
\hline VIII & 2,3-Dihydroxy-1,4-naphthalenedione & & 2.26 & $191,163,131,96$ \\
\hline IX & 1,2-naphthalenediol & & 2.44 & $163,135,118,96$ \\
\hline $\mathrm{X}$ & 1(3H)-isobenzofuranone & & 3.59 & $133,128,118,96$ \\
\hline XI & $\begin{array}{l}\text { 4-[(2,3-dihydroxy-1-naphthyl)diazenyl]- } \\
\text { benzenesulfonate }\end{array}$ & & 4.71 & $346,329,130,98$ \\
\hline XII & $\begin{array}{l}\text { 4-[(2,3,4-trihydroxy-1-naphthyl)diazenyl]- } \\
\text { benzenesulfonate }\end{array}$ & & 5.37 & $362,346,173,128,118$ \\
\hline
\end{tabular}

\section{Conclusions}

This study focused on the removal of a dye (Acid Orange 7, AO7) taken as a pollutant model, by Electro-Fenton (EF) process. In a first step, the operating parameters affecting the EF reaction (i.e. applied current density and catalyst concentration) were investigated in acidic medium ( $\mathrm{pH} 3.0)$ and optimized with regards to degradation kinetic and TOC removal results. The operating conditions to get optimal degradations were $-8.3 \mathrm{~mA} . \mathrm{cm}^{-2}$ and $0.2 \mathrm{mM}$ for applied current density and catalyst concentration, respectively. At these values, the mineralization of $200 \mathrm{~mL}$ of AO7 was $96.2 \%$ after $8 \mathrm{~h}$ treatment. The identification and the evolution of intermediate compounds, as well as the toxicity of the solution, were also examined carefully along the EF process. In order to characterize and to quantify as accurately as possible the formation of by-products, both the volume of solutions $(500 \mathrm{~mL})$ and initial concentrations of pollutant $(1 \mathrm{mM})$ were extended. Twelve aromatic by-products could be revealed by HPLC and LC-MS techniques during the decomposition of AO7. The early formation of toxic aromatic products like 1,2-naphtoquinone or 1,4-benzoquinone was correlated to the increase in solution toxicity reaching $100 \%$ for 100 first minutes of the EF treatment. The subsequent decomposition of these intermediates led to the 
formation of short-chain carboxylic acids and thereby to a drastic decrease of the bacteria luminescence inhibition ratio. Consequently the total detoxification of the solution was accomplished after 270 minutes for AO7. The sequential degradation of pollutants and their intermediates produced inorganic ions such as ammonium, nitrate and sulfate which could be quantified at the end of the electrolysis. Finally two complete pathways of AO7 degradation by the Electro-Fenton process could be built and proposed.

\section{Acknowledgment}

We gratefully acknowledge financial support from Vietnamese government (VIED- Vietnam International Education Development - Project 911) and also the ANR project ECOTS/CELECTRON for supplying of materials and chemicals. Authors are also grateful to LABEX CHEMISYST and internal project PAT/ECOTOX for funding.

\section{References}

[1] V. Andoralov, M. Falk, D. B. Suyatin, M. Granmo, J. Sotres, R. Ludwig, V. O. Popov, J. Schouenborg, Z. Blum, and S. Shleev, "Biofuel cell based on microscale nanostructured electrodes with inductive coupling to rat brain neurons," Scientific reports, vol. 3, p. 3270, 2013.

[2] P. Venkatesan and J. Santhanalakshmi, "Core-Shell Bimetallic Au-Pd Nanoparticles: Synthesis, Structure, Optical and Catalytic Properties," Nanoscience and Nanotechnology, vol. 1, pp. 43-47, 2012.

[3] G. Xia, Y. Lu, and H. Xu, "Electrogeneration of hydrogen peroxide for electro-Fenton via oxygen reduction using polyacrylonitrile-based carbon fiber brush cathode," Electrochimica Acta, vol. 158, pp. 390-396, 2015.

[4] H. C. Arredondo Valdez, G. Garcia Jimenez, S. Gutierrez Granados, and C. Ponce de Leon, "Degradation of paracetamol by advance oxidation processes using modified reticulated vitreous carbon electrodes with $\mathrm{TiO}(2)$ and $\mathrm{CuO} / \mathrm{TiO}(2) / \mathrm{Al}(2) \mathrm{O}(3), "$ Chemosphere, vol. 89, pp. 1195-201, Nov 2012.

[5] L. Thi Xuan Huong, B. Mikhael, C. Joffrey, and C. Marc, "A highly active based graphene cathode for the electro-fenton reaction " RSC Adv., vol. 5, pp. 42536-42539 2015

[6] Thi Xuan Huong Le, Mikhael Bechelany, Joffrey Champavert, and M. Cretin, "A highly active based graphene cathode for the electro-fenton reaction," RSC Adv., vol. 5, pp. 42536-42539, 2015.

[7] T. X. H. Le, C. Charmette, M. Bechelany, and M. Cretin, "Facile Preparation of Porous Carbon Cathode to Eliminate Paracetamol in Aqueous Medium Using Electro-Fenton System," Electrochimica Acta, vol. 188, pp. 378-384, 2016.

[8] T. X. H. Le, M. Bechelany, S. Lacour, N. Oturan, M. A. Oturan, and M. Cretin, "High removal efficiency of dye pollutants by electron-Fenton process using a graphene based cathode," Carbon, vol. 94, pp. 1003-1011, 2015.

[9] A. Özcan, Y. Şahin, A. Savaş Koparal, and M. A. Oturan, "Carbon sponge as a new cathode material for the electro-Fenton process: Comparison with carbon felt cathode and application to degradation of synthetic dye basic blue 3 in aqueous medium," Journal of Electroanalytical Chemistry, vol. 616, pp. 71-78, 2008.

[10] X. Yu, M. Zhou, G. Ren, and L. Ma, "A novel dual gas diffusion electrodes system for efficient hydrogen peroxide generation used in electro-Fenton," Chemical Engineering Journal, vol. 263, pp. 92-100, 2015.

[11] J. González-García, P. Bonete, E. Expósito, V. Montiel, A. Aldaz, and R. Torregrosa-Maciá, "Characterization of a carbon felt electrode: structural and physical properties," Journal of Materials Chemistry, vol. 9, pp. 419-426, 1999. 
[12] E. Brillas, I. Sirés, and M. A. Oturan, "Electro-Fenton process and related electrochemical technologies based on Fenton's reaction chemistry," Chemical Reviews vol. 109 pp. 6570-6631, 2009.

[13] S. Hammami, N. Oturan, N. Bellakhal, M. Dachraoui, and M. A. Oturan, "Oxidative degradation of direct orange 61 by electro-Fenton process using a carbon felt electrode: Application of the experimental design methodology," Journal of Electroanalytical Chemistry, vol. 610, pp. 75-84, 2007.

[14] J. W. Lim and D. G. Lee, "Carbon fiber/polyethylene bipolar plate-carbon felt electrode assembly for vanadium redox flow batteries (VRFB)," Composite Structures, vol. 134, pp. 483-492, 2015.

[15] K. Oh, S. Won, and H. Ju, "Numerical study of the effects of carbon felt electrode compression in all-vanadium redox flow batteries," Electrochimica Acta, vol. 181, pp. 13-23, 2015.

[16] T. Liu, X. Li, H. Nie, C. Xu, and H. Zhang, "Investigation on the effect of catalyst on the electrochemical performance of carbon felt and graphite felt for vanadium flow batteries," Journal of Power Sources, vol. 286, pp. 73-81, 2015.

[17] H.-F. Cui, L. Du, P.-B. Guo, B. Zhu, and J. H. T. Luong, "Controlled modification of carbon nanotubes and polyaniline on macroporous graphite felt for high-performance microbial fuel cell anode," Journal of Power Sources, vol. 283, pp. 46-53, 2015.

[18] S. Cotillas, J. Llanos, M. A. Rodrigo, and P. Cañizares, "Use of carbon felt cathodes for the electrochemical reclamation of urban treated wastewaters," Applied Catalysis B: Environmental, vol. 162, pp. 252-259, 2015.

[19] L. Wang, S. Tricard, L. Cao, Y. Liang, J. Zhao, J. Fang, and W. Shen, "Prussian blue/1-butyl-3methylimidazolium tetrafluoroborate - Graphite felt electrodes for efficient electrocatalytic determination of nitrite," Sensors and Actuators B: Chemical, vol. 214, pp. 70-75, 2015.

[20] L. Zhou, M. Zhou, Z. Hu, Z. Bi, and K. G. Serrano, "Chemically modified graphite felt as an efficient cathode in electro-Fenton for p-nitrophenol degradation," Electrochimica Acta, vol. 140, pp. 376383, 2014.

[21] S. Aquino Neto, T. S. Almeida, L. M. Palma, S. D. Minteer, and A. R. de Andrade, "Hybrid nanocatalysts containing enzymes and metallic nanoparticles for ethanol/O2 biofuel cell," Journal of Power Sources, vol. 259, pp. 25-32, 2014.

[22] K. Murata, K. Kajiya, N. Nakamura, and H. Ohno, "Direct electrochemistry of bilirubin oxidase on three-dimensional gold nanoparticle electrodes and its application in a biofuel cell," Energy \& Environmental Science, vol. 2, p. 1280, 2009.

[23] F. N. Crespilho, M. Emilia Ghica, M. Florescu, F. C. Nart, O. N. Oliveira, and C. M. A. Brett, "A strategy for enzyme immobilization on layer-by-layer dendrimer-gold nanoparticle electrocatalytic membrane incorporating redox mediator," Electrochemistry Communications, vol. 8, pp. 16651670, 2006.

[24] A. Karczmarczyk, A. Celebanska, W. Nogala, V. Sashuk, O. Chernyaeva, and M. Opallo, "Electrocatalytic glucose oxidation at gold and gold-carbon nanoparticulate film prepared from oppositely charged nanoparticles," Electrochimica Acta, vol. 117, pp. 211-216, 2014.

[25] S. Hammami, N. Bellakhal, N. Oturan, M. A. Oturan, and M. Dachraoui, "Degradation of Acid Orange 7 by electrochemically generated $(*) \mathrm{OH}$ radicals in acidic aqueous medium using a borondoped diamond or platinum anode: a mechanistic study," Chemosphere, vol. 73, pp. 678-84, Oct 2008.

[26] E. Brillas and C. A. Martinez-Huitle, "Decontamination of wastewaters containing synthetic organic dyes by electrochemical methods. An updated review. ," Applied Catalysis B-Environmental vol. 166, pp. 603-643, 2015.

[27] M. A. Oturan and J. J. Aaron, "Advanced oxidation processes in water/wastewater treatment: Principles and applications. A review," Critical Reviews in Environmental Science and Technology, vol. 44, pp. 2577-2641, 2014.

[28] M. A. Oturan, J. Pinson, J. Bizot, D. Deprez, and B. Terlain, "An International Journal Devoted to all Aspects of Electrode Kinetics, Interfacial Structure, Properties of Electrolytes, Colloid and Biological ElectrochemistryReaction of inflammation inhibitors with chemically and 
electrochemically generated hydroxyl radicals," Journal of Electroanalytical Chemistry, vol. 334, pp. 103-109, 1992/09/04 1992.

[29] E. Brillas, B. Boye, I. Sirés, J. A. Garrido, R. M. a. Rodríguez, C. Arias, P.-L. s. Cabot, and C. Comninellis, "Electrochemical destruction of chlorophenoxy herbicides by anodic oxidation and electro-Fenton using a boron-doped diamond electrode," Electrochimica Acta, vol. 49, pp. 44874496, 2004.

[30] A. Özcan, Y. Şahin, A. Savaş Koparal, and M. A. Oturan, "Carbon sponge as a new cathode material for the electro-Fenton process: Comparison with carbon felt cathode and application to degradation of synthetic dye basic blue 3 in aqueous medium," Journal of Electroanalytical Chemistry, vol. 616, pp. 71-78, 2008.

[31] K. Hanna, S. Chiron, and M. A. Oturan, "Coupling enhanced water solubilization with cyclodextrin to indirect electrochemical treatment for pentachlorophenol contaminated soil remediation," Water Research, vol. 39, pp. 2763-2773, 2005.

[32] B. Boye, M. Morième Dieng, and E. Brillas, "Anodic oxidation, electro-Fenton and photoelectroFenton treatments of 2,4,5-trichlorophenoxyacetic acid," Journal of Electroanalytical Chemistry, vol. 557, pp. 135-146, 2003.

[33] E. Brillas, E. Mur, R. Sauleda, L. Sànchez, J. Peral, X. Domènech, and J. Casado, "Aniline mineralization by AOP's: anodic oxidation, photocatalysis, electro-Fenton and photoelectroFenton processes," Applied Catalysis B: Environmental, vol. 16, pp. 31-42, 1998.

[34] M. A. Oturan, J. Peiroten, P. Chartrin, and A. J. Acher, "Complete Destruction of p-Nitrophenol in Aqueous Medium by Electro-Fenton Method," Environmental Science \& Technology, vol. 34, pp. 3474-3479, 2000/08/01 2000.

[35] A. K. Abdessalem, N. Oturan, N. Bellakhal, M. Dachraoui, and M. A. Oturan, "Experimental design methodology applied to electro-Fenton treatment for degradation of herbicide chlortoluron," Applied Catalysis B: Environmental, vol. 78, pp. 334-341, 2008.

[36] M. Skoumal, P.-L. Cabot, F. Centellas, C. Arias, R. M. Rodríguez, J. A. Garrido, and E. Brillas, "Mineralization of paracetamol by ozonation catalyzed with Fe2+, Cu2+ and UVA light," Applied Catalysis B: Environmental, vol. 66, pp. 228-240, 2006.

[37] A. Özcan, M. A. Oturan, N. Oturan, and Y. Şahin, "Removal of Acid Orange 7 from water by electrochemically generated Fenton's reagent," Journal of Hazardous Materials, vol. 163, pp. 1213-1220, 2009.

[38] Y. Kumagai, Y. Shinkai, T. Miura, and A. K. Cho, "The chemical biology of naphthoquinones and its environmental implications," Annual review of pharmacology and toxicology, vol. 52, pp. 221-47, 2012.

[39] A. Das, S. Chakrabarty, D. Choudhury, and G. Chakrabarti, "1,4-Benzoquinone (PBQ) induced toxicity in lung epithelial cells is mediated by the disruption of the microtubule network and activation of caspase-3," Chemical research in toxicology, vol. 23, pp. 1054-66, Jun 212010.

[40] A. Dirany, I. Sires, N. Oturan, A. Ozcan, and M. A. Oturan, "Electrochemical treatment of the antibiotic sulfachloropyridazine: kinetics, reaction pathways, and toxicity evolution," Environmental science \& technology, vol. 46, pp. 4074-82, Apr 32012.

[41] J.Devillers, P.Boule, P.Vasseur, P.Prevot, R.Steiman, F.Seigle-Murandi, J.L.Benoit-Guyod, M.Nendza, C.Grioni, D.Dive, and P.Chambon, "Environmental and health risks of Hydroquinone," Ecotoxicology and Environmental Safety, vol. 19, pp. 327-354, 1990.

[42] J. A. Zazo, J. A. Casas, C. B. Molina, A. Quintanilla, and J. J. Rodriguez, "Evolution of Ecotoxicity upon Fenton's Oxidation of Phenol in Water," Environmental science \& technology, vol. 41, pp. 7164-7170, 2007.

[43] E. Seker, M. L. Reed, and M. R. Begley, "Nanoporous Gold: Fabrication, Characterization, and Applications," Materials, vol. 2, pp. 2188-2215, 2009.

[44] P. Bansal, D. Singh, and D. Sud, "Photocatalytic degradation of azo dye in aqueous TiO2 suspension: Reaction pathway and identification of intermediates products by LC/MS," Separation and Purification Technology, vol. 72, pp. 357-365, 2010. 
[45] T. Velegraki, I. Poulios, M. Charalabaki, N. Kalogerakis, P. Samaras, and D. Mantzavinos, "Photocatalytic and sonolytic oxidation of acid orange 7 in aqueous solution," Applied Catalysis B: Environmental, vol. 62, pp. 159-168, 2006.

[46] H.-Z. Zhao, Y. Sun, L.-N. Xu, and J.-R. Ni, "Removal of Acid Orange 7 in simulated wastewater using a three-dimensional electrode reactor: Removal mechanisms and dye degradation pathway," Chemosphere, vol. 78, pp. 46-51, 2010. 